\title{
RECRUITMENT AND FOREST POLICY
}

$\mathrm{A}^{\mathrm{n}}$ FTER seventy years of forest administration in India and Burma, and nearly forty years in some of the British Colonies, it is disturbing to realize how little the importance of the forest wealth of some of the countries in question is understood in Great Britain or by the responsible administration. The general attitude of administrators is apparently that forest property, especially great areas of tropical and semi-tropical forests, can be left to look after themselves when any period of stress, financial or otherwise, eventuates. These ideas are strongly entrenched in Government circles, particularly in London.

The present position with regard to the training of foresters is causing considerable concern. Whereas men taking certain technical degrees at universities are to complete their studies before being called up for military (or other) service, those taking a pass degree in forestry are not to be retained. This action has been taken apparently after referring solely to the Forestry Commission, which, being at present chiefly a spending department, has of necessity ceased recruiting. In reply to a recent inquiry the Ministry of Labour and National Service stated that the experience of the Central Register is that the demand for pass degree forestry men is almost non-existent. The Central Register has apparently been notified of only two vacaricies for such men over the last six months, and both these were offered by the Sudan Government. The position with regard to the demand for agricultural students is of course very different.

The information thus conveyed is not even accurate. At about the time of, or slightly before, the offer of the Sudan appointments, the Punjab Government was offering two appointments for men possessing forestry degrees and was unable to obtain them. Further, the Colonial Office, though much slowed down, had not ceased recruiting. The recollection there was only too vivid, as it should be in India also, of the crucial difficulties in connexion with filling the ranks of forestry services after the War of 1914-18; and of the troubles which inevitably resulted from recruiting excessively large annual batches often inefficiently, because hurriedly, trained.

It may be asked, it being incontrovertible that the millions of the peasant agricultural populations are in one way or another dependent upon these great forest regions in the British Empire, whether ministers and their deputies responsible for the administration of these several countries really understand the position. The forest departments have been cut down, by allowing junior officers to join the Fighting Services and reducing annual recruitment. At the same time, it is well known that enhanced fellings are taking place to provide for military requirements. No forest, whatsoever its type, can stand this kind of treatment without serious deterioration. Moreover, such fellings are often, in the absence of the supervision of trained and responsible forest officers, put into the hands of uncontrolled timber contractors who have no other interest than to complete their contracts at whatever the cost in destruction to the forests.

Under the British system of Colonial administration, it is constantly reiterated that we are governing the countries in the interests of the people, and that when they are ready the government will be entrusted to them. But how are the forests being treated? What will be their condition when we make over this charge? The old Colonial policy was to give a long lease of a block or blocks of forests to a big timber company which paid a royalty, usually so much per tree felled; and it was considered that such arrangements were in the interest of the development of the Colony. Many fine forests have disappeared under this treatment-but their marketable value, that is, the money resulting, mostly left the country. Take, for example, Nigeria at the present time, and the valuable mahogany timber. Under present conditions, Government, that is, the people, obtain about $£ 4$ in royalty for a tree selling at present prices for more than $£ 100$-and much of this difference goes out of the country. Further, the forests so worked are not under the supervision of trained forest officers.

War does not stop the working of these tropical forests ; it tends to enhance it. The staff requires additions, not cuts-as should be evident, if the case were rightly understood, to a wide-visioned administrator. It is not a question of planning ahead. Rather it is that of fulfilling a sacred obligation to the people we govern by handing down to their successors a better heritage ; and that the present profits should be spent on the people themselves.

The Secretary of State for the Colonies recently said in the House of Lords : "Not only colonial trade but also colonial development in the widest sense will inevitably have to be regulated and controlled by Government much more than was necessary before the War." The position of forestry in the British Colonies may be commended to the personal attention of the Secretary of State. 